\title{
RESPONSE OF CUCUMBER AND OKRA TO COMBINED APPLICATION OF AZOTOBACTER TRANSFORMANTS AND CHEMICAL NITROGEN FERTILIZER Hassan,E.A. ${ }^{1}$;Manal A. Abd Allah ${ }^{1} ; K$. A. Abd Elaziz ${ }^{1}$ and O.F. Dakhly ${ }^{2}$ \\ ${ }^{1}$ Veg. Res. Dept., Hort. Res. Inst. Agric. Centre, Ciza, Egypt, ${ }^{2}$ Genetic Dept., Fac., of Agric. Minia University
}

\section{ABSTRACT}

The present investigation was carried out (Lab. study) in microbial genetics lab., Genetic Dept., Minia University and a field study was carried out at Sakha agriculture research station farm during the two successive summer season of 2004 and 2005.

DNA extract from Bacillus sp. (grown under $20 \% \mathrm{NaCl}$ ) was used transform salt isolate to sensitive isolates of Azotobacter vinelandii Wild type. The producing transformants were used to infect cultivars of cucumber (hybrid prince) and Okra Eskandrandi).

Results showed that the highest frequencies of transformants $\left(330 \times 10^{-6}\right)$ was obtained on $10 \% \mathrm{NaCl}$ at 24 hours.

Results also, indicated that there were significant differences in growth characteristics between the plants inoculated with the tested strains when compared with the control plants (non-inoculated) or the plants inoculated with the wild type strain. All transformants in our study had the best effect on most growth characters and yield as compared with wild type strain.

The best transformants was T-4 which had the highest percentage of increasing total yield with both crops. The data show that there were differences among both, methods of incubation (Liquid or capsules) in their effects on the two crops in their response. The best method was liquid which had the highest values of all growth characters and total yield.

Finally, the present investigation recommends the importance of inoculating vegetables crops with transformants of $A$. vinelandii to improve their growth and yield with using the liquid method.

Keywords: Okra, cucumber, (Cucumis sativus, L); Azotobacter vinelandii, Azotobacter transformants

\section{INTRODUCTION}

The cucumber (Cucumis sativus) is a widely cultivated plant in the gourd family Cucurbitaceae. Though it technically is a fruit, cucumbers are widely considered vegetables. Many alternative health practitioners believe all disease begins in the colon. The okra fiber, absorbing water and ensuring bulk in stools, helps prevent and improve constipation. Fiber in general is helpful for this but okra is one of the best, along with ground flax seed and psyllium (Sylvia W. Zook, 2002).

Okra is commonly used in Southern, Creole, and Cajun cooking. This is due to the fact that it was initially introduced into the United States in its southern region. Since there is little frost in the southern region, okra grows well there. Okra is low in calories and is a good source of many nutrients including vitamin $\mathrm{B}_{6}$, and L-Ascorbic acid (vitamin $\mathrm{C}$ ), fiber, calcium, and folic acid. It is effective for the prevention of neural tube defects in developing 
Hassan,E.A. et al.

fetuses mainly due to its high content of vitamin $\mathrm{B}_{6}$, calcium, fiber, and folic acid. United States imports a large volume of okra. According to the USDA report, in 2002, United States imported 21,022 metric tones (MT) of okra, in which, 97\% of it came from Mexico (kochhar@physiology.wisc.edu)..

All members of the family Azotobacteraceace can fix, atmospheric nitrogen, Azotobacters are aerobic, mainly soil- dwelling organisms with allniquc array of metabolic capabilities in addition to nitrogen fixation. Different species and strains have various abilities to synthesize alginates, polyhydroxybutyrate ( $\mathrm{P}-\mathrm{OHB}$ ) and plant hormones (Elessawy et al., 1984; Gonzalez et al., 1986 and Horan et al., 1983).

Developments in molecular biology and methods available for genetic manipulation in Azotobacters have made possible the genetic analysis of nitrogen fixation and related aspects of nitrogen metabolism. Chromosome mobilization mediated by conjugative plasmids and transformation occurs in $A$. vinelandii and $A$. bejerrink.

The frequency of nif gene transfer from wild type $A$. vinelandii to $A$. vinelandii nif mutants is $10^{-4}-10^{-5}$ per recipient using R.68 and $10-8$ using Rp4.

Urea was applied at $50 \mathrm{~kg} \mathrm{~N}^{1}$ to supply adequate nitrogen to okra. Each of the pots was provided with two drainage holes and a saucer. The treatments were thoroughly mixed with the soil and moistened with water for one week for proper equilibration. The treatments were replicated three times in a completely randomized block design (CRBD) (Oluwatoyinbo et al., (2005). The response of two okra varieties ("White velvet "and "NHAE 47-4" ) to fertilization was studied by Majanbu et al., (2005) in northern Nigeria using four rates of nitrogen $\left(0,25,50\right.$ and $\left.100 \mathrm{~kg} \mathrm{ha}^{-1}\right)$. Nitrogen application significantly increased green pod yield, pod diameter, number of fruits per plant, number of seeds per pod and pod weight. The two varieties responded to nitrogen application differentially with respect to green pod yield. For optimum green pod yield of "White velvet $35 \mathrm{~kg} \mathrm{~N}^{3} \mathrm{~h}^{-1}$ is suggested while for variety NHAE $47-4^{3}, \mathrm{~N}$ fertilization can be increased to $70 \mathrm{~kg} \mathrm{ha}^{-1}$.

The aims of the present investigation were:-

1- Studying the role of Azotobacter vinelandii to reduce or eliminate the harmful effects of salinity cucumber and Okra plants. 2- To improve the potentially of the existing isolates of Azotobacter vinelandii, and 3- evaluating the enhancement of salt-tolerance of cucumber and Okra plants.

\section{MATERIALS AND METHODS}

This investigation was carried out at the Genetics Dept. Faculty of Agriculture, Minia University and a field experiment was carried out at Sakha Agriculture research station during the two successive summer seasons of 2004 and 2005.

\section{I- Laboratory experiments:}

\section{A- Strains:-}

1- Azotobacter vinelandii strain which was isolated in Genetics laboratory (Abdel-Rahem et al., 1995). 
2- Halobacterium sp. Strain isolated from sea water as described by Dakhly (1993).

3- The members of this genus are able to grow over a wide salinity range from 10 to $0 \%$ total salts (Mullakhanbhal and Larsen, 1975). This isolate was used as a donor parent.

\section{B- Media:-}

1- Complete medium (CM), was used for Azotobacter vinelandii culturing (Strandberg and Wilson, 1968).

2- Nutrient agar medium was used to grow the isolate of Halobacterium (Dakhly 1993).

c. DNA extraction:-

DNA from strain (Halophilic bacteria) was isolated and purified according to Ausubel et al., (1987).

D. Transformation procedure:-

According to Rifaat et al., (1974)

Inocula preparation:-

1- Free cells inoculums:-

The most efficient Azotobacter vinelandii transformants were propagated singly in conical flasks $100 \mathrm{ml}$ containing $500 \mathrm{ml}$. of the nutrient both medium inocula with a loop-full of 48 hours old culture. For preparation of heavy free call inoculate of field experiments, the efficient Azotobacter vinelandii transformant isolates were propagated singly on nutrient agar medium. The suspension was used for seedling inoculation. The heavy microbial cell inocula contained from 108 to 109 viable cells per ml. as determined by the plate count method.

\section{2- Immobilized cells inoculums (capsules):-}

An appropriate volume of the active Azotobacter vinelandii transformants free cell suspension was mixed with an equal volume of a sterilized cool sodium alginate $(50 \% \mathrm{w} / \mathrm{v})$. The final alginate concentration upon dilution with the active free-cells suspension was $2.5 \%(\mathrm{w} / \mathrm{v})$. The mixture was extruded through a sterile. Pasteur pipette into a sterile $3 \%$ $\mathrm{CaCl}_{2}(\mathrm{w} / \mathrm{v})$. Beads of approximately $2 \mathrm{~mm}$ diameter were formed and were hardened in $3 \% \mathrm{CaCl}_{2}$ solution for 2 hours before washing.

The beads were washed with served rinses of sterile distilled water. Before use, beads were blotted dry on filter paper. Viable cell counts in the beads ranged from $10^{7}$ to $10^{8} / \mathrm{g}$ beads. The prepared heavy free cell suspensions of Azotobacter microorganisms were used to prepare heavy sodium alginate immobilized cell inocula as described above for field experiments. The obtained alginate capsules were used as seedling inocula. The viable cell counts in the beads before use were $10^{8}-10^{9} \mathrm{gm}$. beads.

II- Field experiments:

Two vegetable crops i.e. cucumber (hybrid prince) and Okra cv. Eskandrani were used.

Three transformants of Azotobacter vinelandii addition to wild type strain were used for plant inoculation. Three rates of nitrogen fertilizers i.e. $0.0,150$, and $300 \mathrm{~kg}$ of ammonium sulphate were used as sources for chemical nitrogen fertilizer. Finally, two methods of inoculation: used 
Hassan,E.A. et al.

suspension for seed inoculation or put a capsule of isolates and transformant beside the plants.

The seeds of both cucumber and okra plants were inoculated with liquid transformants before sowing. The sowing data was at April $16^{\text {th }}$ and April $18^{\text {th }}$ in both seasons for cucumber and okra respectively.

The cucumber seeds were sowing on ridges $3 \mathrm{~m}$ long and $1 \mathrm{~m}$ width, while the distance between hills was $30 \mathrm{~cm}$, while, the distance between hills was $60 \mathrm{~cm}$ for Okra plants.

The RCBD (randomized complete block design with three replicates were used. Whereas, the three nitrogen rates were distributed in main plots and methods of inoculation (suspension or capsules) in subplots the three transformants addition to wild type strain and control plants were distributed in sub-sub plots.

At full blooming stage, ten plants were randomly taken from each experimental unit and the number of fruits/plant, weight of fruit/plant, stem lengths $(\mathrm{cm})$ and number of leaves/plants were measured.

Statistical analysis:

Data were subjected statistically to analysis of variance according to Streel and Torric (1960). Least significant difference (LSD) was calculated to compeer between treatment means others than the control.

\section{RESULTS}

Number of recipient cells $/ \mathrm{ml}$ and number of transformants as well as the percentages of transformants after 5 days of incubation at $30^{\circ} \mathrm{C}$ were presented in Table (1).

Table (1): Number and percentage of Azotobacter vinelandii transformants grown on complete media supplemented with 10 or $15 \%$ of $\mathrm{NaCl}$.

\begin{tabular}{|c|c|c|c|c|}
\hline \multirow[b]{2}{*}{ Treatments } & \multicolumn{2}{|c|}{$12 \mathrm{hrs}$} & \multicolumn{2}{|c|}{$24 \mathrm{hrs}$} \\
\hline & $10 \% \mathrm{NaCl}$ & $15 \% \mathrm{NaCl}$ & $10 \% \mathrm{NaCl}$ & $15 \% \mathrm{NaCl}$ \\
\hline $\begin{array}{|lll|}\text { No. } & \text { control } & \text { (recipient } \\
\text { cells) } & & \\
\end{array}$ & $\begin{array}{l}{ }^{*}(1) 122000 \\
100 \%\end{array}$ & $\begin{array}{c}122000 \\
100 \%\end{array}$ & $\begin{array}{c}122000 \\
100 \%\end{array}$ & $\begin{array}{c}122000 \\
100 \%\end{array}$ \\
\hline $\begin{array}{l}\text { On complete media \% } \\
\text { No. control } \\
\text { cells) }\end{array}$ & $\begin{array}{l}*(2) 0.00 \\
0.00\end{array}$ & $\begin{array}{l}0.00 \\
0.00\end{array}$ & $\begin{array}{l}0.00 \\
0.00\end{array}$ & $\begin{array}{l}0.00 \\
0.00\end{array}$ \\
\hline $\begin{array}{l}\text { On selective media \% } \\
\text { No. transformants \% }\end{array}$ & $\begin{array}{c}32.00 \\
00.26 \times 10^{-3}\end{array}$ & $\begin{array}{c}4.0 \\
0.32 \times 10^{-6} \\
\end{array}$ & $\begin{array}{c}40.0 \\
0.33 \times 10^{-3} \\
\end{array}$ & $\begin{array}{c}6.0 \\
0.19 \times 10^{-6} \\
\end{array}$ \\
\hline
\end{tabular}

*(1)-Azotobacter vinelandii (recipient cells) when grown on complete media without salts.

*(2)-Azotobacter vinelandii (recipient cells) when grown on complete media with salts (10 or $15 \% \mathrm{NaCl})$.

Data in Table (1) show that the extracts DNA from Bacillus spp gave the $\mathrm{NaCl}$ sensitive cells of Azotobacter vinelandii the ability to be salt tolerant. It can be observed also that percentages of transformants were $260 \times 10^{-6}$ on $10 \% \mathrm{NaCl}$ and $32 \times 10^{-6}$ on $15 \%$ at 12 hours but $330 \times 10^{-6}$ on $105 \mathrm{NaCl}$ and $49 \times 10^{-6}$ on $15 \%$ at 24 hours. In this respect, Gabor (1965) Orgara and Duncan (1973) Heumann and Springer (1977) and Abdel Halim and Ali 
(1990) studied transformation of "OSm" genes from Bacillus spp. To $R$. leguminosarum and $R$. lupine. They found that the mean frequency of transformants was $21 \times 10^{-5}$ for $R$. leguminosarum while it was $15 \times 10^{-5}$ for $R$. lupine.

\section{Field characters (cucumber):}

1-Number o fruits/plants:-

The data presented in Table (2) showed that there is increasing values of the plants inoculated with four transformants of Azotobacter vinelandii in number of fruits/plant compared with uninoculated plants in both seasons. Two methods of inoculation differed significantly each from other in both seasons. However, liquid showed significantly higher values compared to the capsules method. Increasing $\mathrm{N}$-rate increased number of fruits/plant. The yield increases, possible earlier maturity, and a higher total $\mathrm{N}$ in the tops may have been stimulated by bacterium produced phytohormones Tien et al., (1979) which suggested improve plant growth by their direct effects on metabolic processes. The interactions among tree treatments showed significant effects on this trait.

\section{2- Weight of fruits:-}

Weight of total fruits/plant (Table 3) was also increased significantly after inoculation with Azotobacter transformants compared with (control) plants (without nitrogen fertilizers). T2 was the best transformant which showed the highest values of weight of total fruits/ plant in both seasons. Also, weight of fruits/plant was increased significantly as rate of chemical nitrogen increased as shown in Table (3). The interaction between chemical nitrogen and methods of inoculation were significant in first season but nonsignificant in second season for this trait. Also, the interaction between transformants and nitrogen closes were significant in both season for weight of fruits/plant.

The interaction between chemical nitrogen, methods of inoculation and transformants were significant in both seasons. This is in agreement with the results obtained by Tien et al., (1979) suggested improve plant growth by their direct effects on metabolic processes. The yield increases, possible earlier maturity, and a higher total $\mathrm{N}$ may have been stimulated by bacterium produced phytohormones.

\section{3- Growth characters of cucumber (steam length after 60 days and number of leaves after $\mathbf{4 5}$ and $\mathbf{6 0}$ days)}

Data presented in Table (4) showed that both of stem length and leaves number/plant of cucumber plant were significant affected by both nitrogen rates and inoculation with different transformants of Azotobacter while the methods of inoculation had insignificant. Cucumber plant length and number of leaves were significantly increased with inoculation by transformants. T4 was the best transformant showed the highest plant $(137.3 \pm 4.9$ and $161.6 \pm 7.84)$ in the first and second seasons, respectively. The number of leaves were increase after inoculation with T4 $(61.17 \pm 2.14$ and $58.78 \pm 14.39$ ) in the first and second seasons respectively. These results were in the same trend with those obtained by Barea and Brown (1974) ElShehaby (1981). 
Hassan,E.A. et al.

T2-3 
J. Agric. Sci. Mansoura Univ., 33(8), August, 2008

$\mathrm{T} 4$

5941 
Hassan,E.A. et al.

b-Okra:

1- Growth characters:-

Data presented in Table (5) showed that the inoculation Okra plants with transformants of Azotobacter vinelandii increased plant length compared with uninoculated plants. Chemical nitrogen rates were different significantly in plant length. Also, data presented in Table (3) showed that number of levels of Okra plants was affected by inoculation with Azotobacter vinelandii transformants in both seasons. On the other hand, the chemical fertilizer rates showed significant effect on these traits the interaction effects showed significant differences on these traits. The highest values of these traits were obtained with fertilized okra plants with highest rate of fertilizer (300 kg N/ed.) and inoculation these plants with (T1). These results are in partial agreement with those obtained by Osman et al., (1990) that increasing $N$ levels had increased leave weights.

2-Yield and yield components:-

Data presented in Table (6) showed that the inoculation process of okra plant with $A$. vinelandii transformants had significant effects on number of fruits/plant and weight of fruits/plant in both season. On the other hand the high rates of nitrogen fertilizer showed significant increased in number of fruits/ plant and weight of fruits/plant in both seasons compared to the lower rate as shown in Table (3).

Regarding to the interaction, effects data show that significant differences, the highest number of fruits/plant $(974.7 \pm 58.40$ and $755.3 \pm 26.10)$ were obtained offer inoculation with (T1) in the first and second season respectively and fertilization with $300 \mathrm{~kg} \mathrm{~N} /$ Fed. of chemical fertilizer (Table 7). These results are in similar with those obtained by Foly et al., (2002), Dakhly and Abdel-Mageed, (1997) and Dakhly (1993).

Prabhjeet et al., (1994) inoculated Rape cv. ISN-129 grown at New Delhi in 1988/89 with $A$. chroococcum by coating the seeds with bacteriacontaining peat and was given 0,20 or $40 \mathrm{~kg} \mathrm{~N} / \mathrm{ha}$. Both inoculation and applied $\mathrm{N}$ increased seed yield. The response to $A$. chroococcum was greatest in the absence of $\mathrm{N}$ fertilizer, while the highest overall seed yield was given by $40 \mathrm{~kg} \mathrm{~N}$ plus inoculation. The yield increase in response to inoculation was attributed to a greater number of primary branches and pods, associated with a higher LAl, particularly at the pod-filling stage, and a faster CGR. Yield component data is tabulated.

\section{DISCUSSION}

The major problem facing the farmer is the high cost of chemical fertilizers. Furthermore, chemical fertilizer production and utilization are considered to be an air, soil and water polluting agent. Therefore, the utilization of transformants, biostimulants and biofertilizers are considered today by many scientists as a promising alternative, particularly for developing countries. The importance of use of bio-manure or mineral fertilizers in tropical agriculture and in increasing world food production had been thoroughly discussed (Abad et al., 1997). 
J. Agric. Sci. Mansoura Univ., 33(8), August, 2008 T5 


\section{Hassan,E.A. et al.}


J. Agric. Sci. Mansoura Univ., 33(8), August, 2008

t7

5945 
Hassan,E.A. et al.

In most cases, single applications of these organic manure or mineral fertilizers are carried out (Akanbi and Togun, 2002). There is little attention on combine effect of organic and mineral fertilizers. The little available information on the crop response to joint application of chemical fertilizer and organic manure centered on the agronomy of production (Akanbi and Togun, 2002). With the current move towards increased food production in Egypt, it has become necessary to study how yield of okra is affected by time of application of organic and inorganic fertilizers so as to allow a good economic comparison between the two fertilizer types and their time of application also, method o application of biofertilizers.

Oluwatoyinbo et al., (2005) concluded that for optimum performance of okra, on acid soil application of lime and phosphorus fertilizer at $500 \mathrm{~kg} \mathrm{ha}^{1}$ and $10 \mathrm{~kg} \mathrm{ha}^{1}$, respectively is beneficial. They added that the presence of lime ameliorates soil acidity and adequate lime reduces the amount of fertilizer phosphorus required for good crop growth and fruit yield. This, it does through its ability to neutralize soil acidity and the subsequent effects of increasing available $\mathrm{P}$ and $\mathrm{Ca}$.

Akanbi et al., (2006) concluded that based on the yield response and economic indicators, it pays better to apply combination of 2 ton /ha compost $+30 \mathrm{~kg}$. N /ha for okra fertilization in the humid forest zone of Nigeria. This treatment produced a favourable 1. 8:1 benefit: cost ratio and had an increased in net returns of 59 and $47 \%$ above the $4 \mathrm{t}$. /ha compost and use of recommended NPK mineral fertilizer treatment, respectively.

Finally, the optimum conditions for Okra and cucumber need more extensive studies in next ten years. The efficiency of the conjunctive application of the organic and inorganic fertilizer could be improved by split application at planting and 3 weeks after planting.

\section{REFERENCES}

Abad, M.B., Clement, M. D. Aragan, R. P. and Camarero. A. S. (1997). The influence of solid Urban waste compost and nitrogen mineral fertilizer on growth and productivity in potatoes. Commun. Soil Sci. plant anal. 28 (17 \& 18): 16531661.

Abdel Halim, A. and Ali, A.M.M. (1990): The chromosomal acceptance of osmoregulatory genes (OSM) from Bacillus $s p$. In two Rhizobia species. African Journal of Agriculture Sciences, 17: 241-259

Abdel-Rahem, A.T., Ragab, R.A, Dakhly, O.F and Eid, R.A. (1995): Improvement of $A$. vinelandii efficiency for nitrogen fixation through mutation induction and conjugation. Egypt. Appl. Sci., 10(8): 753-771.

Akanbi, W.B. (2002). Growth, nutrient uptake and yield of maize and okra as influenced by compost and nitrogen fertilizer under different cropping systems. Ph. D. Thesis, University of Ibadan, Nigeria. 228pp.

Akanbi, W. B. and Togun, A. O. (2002). The influence of maize- Stover compost and nitrogen fertilizer on growth, yield and nutrient uptake of Amaranth. Scientia Horticulturae, 93: 1-8. 
Akanbi, W.B; Adediran, J.A, Olaniyan, A.B and Togun, A.O. (2006): An Economic Analysis of Split Application of Organo-mineral Fertilizer on Okra in Humid Forest Zone of Nigeria. Ann. report in International Institute of Tropical Agriculture (IITA), pp.1-9.

Ausubel, F.; R. Brent, R. Kingston, D. Morre, J. Seidman and K. Struhl (1987): Current protocols in Molecular Biology. Johan Wiled and Sons, New York.

Barea, J.M. and M.E. Brrown (1974): Effects on plant growth produced by Azotobacter paspali related to synthesis of plant growth regulating substances. J. Appl. Bact., 37: 584-593.

Dakhly, O.F. (1993): Symbiotic efficiency of salt tolerant transformants of two rhizobium SPegypt, grenet. Cytal. 22:131-144.

Dakhly, O.F. and Y.T. Abdel-Mageed (1997): Estimation of effectiveness of Azotobacter chroococum transformants on growth and yield of some vegetable crops. Egypt. J. Grenet Cytal., 26: 73.

Elessawy, A.A.; M.A. Elsayed, Y.A., Mohamed and Elshanshoury (1984): Effect of companied nitrogen in the production of plant growth regulators by Azotobacter chroococum. Zentra 121, Microbial 139: 327333.

El-Shehaby, A.F.. (1981): $\mathrm{N}_{2}$-Fixing bacteria in the rhizosphere of certain plants. M.Sc. Thesis, Fac. of Agic. Cairo Univ. Egypt.

Foly, H.M.H.; O.F. Dakhly; El-Mawad; Y. Abdel-Mageed and E.A. Hassan (2002): Using some isolates and transformants of Azotobacter to reduce chemical nitrogen fertilizer rates in garlic production. J. Agric. Sci. Mansoura Univ., 27(11): 7667-7684.

Gabor, M. (1965): Transformation of streptomycin markers in Rough stairs of $R$. lupine. II- The relation between the determinant of streptomycin dependence and those for streptomycin resistance and sensitiveness genetics. 52: 905-913.

Gonzalez-Lobez, J., V. Salmeron, M.V. Martinez Toledo; Ballesteros and A. Ramons-Cormenzana (1986): Production of auxins, gibberellins and cytokinins by Azotobacter vinelandii ATCC 12837 in chemically defined media and dialyzed soil media. Soil. Biol. Biochem. 18:119-120.

Heumann, W. and Springer, R. (1977): Formation of merodiploid donors by conjugation in R. Spring (1977) Formation of merodiploid donors by conjucefation in R. pupini. Mol. Genet., IOS (1): 73-79.

Horan, N.J.; R. Jarman and E.A. Dawes (1983): Studies on some enzymes of aliginic acid biosynthesis in Azotobacter vinelandii grown in continuous culture. J. Gen. Microbial., 129:2985-2990.

kochhar@physiology.wisc.edu).. Internet References, Yahoo.com, Search Engine

Majanbu, I.S.; Ogunlela, V.B. Ahmed, M.K. and Olarewaju, J.D. (2005): Response of two okra (Abelmoschus esculentus L. Moench) varieties to fertilizers: Yield and yield components as influenced by nitrogen and phosphorus application. Nutrient Cycling in Agroecosystems. Volume 6, Number 3. 257-267

Mullakhanhai, M.F. and Larsen, I.L. (1975): Halobacterium valcanii spec. Nov., a dead Sea Halobacterium with a moderate salt requirement. Arch Microbial. 104:207-214. 
Hassan,E.A. et al.

Oluwatoyinbo, F.I.; Akande, M.O. and Adediran, J.A. (2005): Response of Okra (Abelmoschus esculentus) to lime and phosphorus fertilization in an acid soil. World Journal of Agricultural Sciences 1 (2): 178-183, 2005

Orgara, A. and Duncan, L.K. (1973): Transformation and physical properties of R.Factor (Rp4) transferred from E. coli to R. trifolii. J. Bacterrial., 116: 1177-1180.

Osman, A.Z.I; Abdel-Hameid, A.M. and Farrag, M.M. (1990): Effect of plant density and nitrogen levels on growth and bulb quality of garlic cultivar "Chinese". Minia J. Res. and Dev., 12(4): 2394-2407.

Prabhjeet, S.; Bhargava, S.C, and Singh-P (1994): Changes in growth and yield components of Brassica napus in response to Azotobacter inoculation at different rates of nitrogen application. Journal-ofAgricultural-Science. 1994, 122: 2, 241-247.

Rifaat, O.M.; K.A.A. Ahmed; Y.A. Hamdi and S.M. Abdel-Wahab (1974): Interstrain transformation of antibiotic resistance $R$. trifolii. Egypt, J. Genet. Cytol., 3:68-78.

Strandberg, G.W. and P.W. Wilson, (1968): Formation of the nitrogen fixing enzyme stem in Azotobacter vinelandii. Can J. Mirobial., 14: 25-31.

Streel, R.G. and H. Torric (1960): Principle and procedures of Statistics. McGrow-Hill. Inc. Toronto, Canada.

Sylvia W. Zook, (2002): Nutritional Significance of fiber vegetables (Okra and cucumber). Review article published under Web-site (kochhar@physiology.wisc.edu).

Tien, T.M.; M.H. Gaskina; D.H. Hubbell (1979): Plant growth substances produced by Azospirillum brasilense and their effect on the growth of pearl millet. Appl. Environ. Microbial. 37:1016-1024.

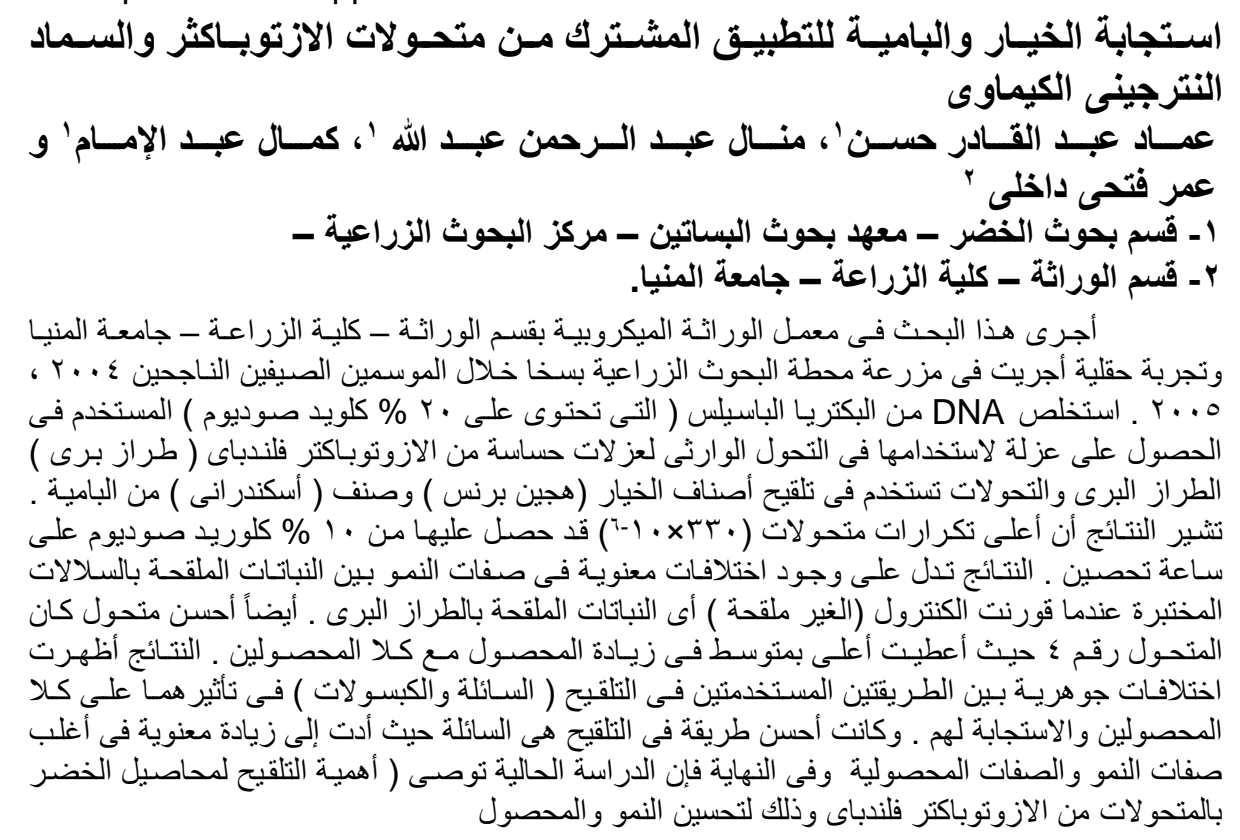


Table (2): Effects of Azotobacter transformants and chemical nitrogen rates on growth characters and yield (gm/plant) of cucumber seasons 2004 and 2005.

\begin{tabular}{|c|c|c|c|c|c|c|c|c|c|c|c|c|c|c|}
\hline \multirow{3}{*}{\begin{tabular}{|l|}
$\mathbf{N}$ \\
$\mathrm{N} 1$ \\
\end{tabular}} & \multirow{3}{*}{$\begin{array}{l}\mathbf{M} \\
1\end{array}$} & \multirow{3}{*}{ s } & \multirow{2}{*}{\multicolumn{2}{|c|}{$\begin{array}{ll}\text { No. of fruits/plant } \\
2004 & 2005\end{array}$}} & \multirow{2}{*}{\multicolumn{2}{|c|}{$\begin{array}{l}\text { Weight of fruits } \\
2004 \quad 2005\end{array}$}} & \multirow{2}{*}{\multicolumn{2}{|c|}{$\begin{array}{l}\text { Stem length (cm) } \\
2004 \quad 2005\end{array}$}} & \multirow{2}{*}{\multicolumn{2}{|c|}{$\begin{array}{ll}\text { No. of leaves/plant } \\
2004 & 2005\end{array}$}} & \multirow{2}{*}{\multicolumn{2}{|c|}{$\begin{array}{cc}\text { Stem length (60d) } \\
2004 & 2005\end{array}$}} & \multicolumn{2}{|c|}{ No. of leaves/plant (60d) } \\
\hline & & & & & & & & & & & & & 2004 & 2005 \\
\hline & & & 285.9 & 256.4 & 29.04 & 21.91 & 71.67 & 99.63 & 26.42 & 32.54 & 156.3 & 176.1 & 73.33 & 66.67 \\
\hline $\mathrm{N} 2$ & 1 & 1 & 177.3 & 216.5 & 18.09 & 18.32 & 64.71 & 84.00 & 24.21 & 24.38 & 125.1 & 159.9 & 45.58 & 48.17 \\
\hline $\mathrm{NO}$ & 1 & 1 & 133.9 & 188.0 & 13.27 & 15.85 & 71.08 & 75.38 & 20.88 & 19.45 & 111.1 & 128.1 & 42.96 & 39.50 \\
\hline \multicolumn{3}{|l|}{ F test } & ** & ** & $\star \star *$ & $\star \star *$ & n.s & $\star * *$ & $\star *$ & $\star *$ & $* *$ & $\star * *$ & $\star \star *$ & $* *$ \\
\hline \multicolumn{3}{|c|}{ L.S.D. 0.05} & 19.26 & 24.48 & 1.99 & 1.60 & - & 2.84 & 1.90 & 1.23 & 3.6 & 14.3 & 3.84 . & 3.84 \\
\hline 1 & M1 & 1 & 208.1 & 218.2 & 20.86 & 18.79 & 73.72 & 93.00 & 24.75 & 25.31 & 130.6 & 155.6 & 52.89 & 50.39 \\
\hline 1 & M2 & 1 & 189.9 & 222.4 & 19.41 & 18.61 & 64.58 & 79.67 & 22.92 & 25.60 & 131.0 & 153.9 & 55.03 & 52.50 \\
\hline \multicolumn{3}{|l|}{$F$ test } & & n.s & & n.s & & & & n.s & n.s & n.s & n.s & n.s \\
\hline 1 & 1 & $\mathrm{~S} 1$ & 189.3 & 212.4 & 19.91 & 18.80 & 69.56 & 84.67 & 22.56 & 24.58 & 128.8 & 146.7 & 48.06 & 47.61 \\
\hline 1 & 1 & $\mathrm{~S} 2$ & 187.6 & 206.5 & 20.82 & 18.89 & 68.39 & 86.33 & 24.17 & 25.19 & 125.1 & 153.6 & 51.72 & 48.83 \\
\hline 1 & 1 & S 3 & 204.1 & 234.8 & 19.65 & 18.86 & 65.56 & 86.11 & 22.94 & 24.33 & 132.0 & 157.1 & 54.89 & 50.56 \\
\hline 1 & 1 & S 4 & 215.1 & 227.5 & 20.15 & 18.24 & 73.11 & 88.22 & 25.67 & 27.71 & 137.3 & 161.6 & 61.17 & 58.78 \\
\hline \multicolumn{3}{|l|}{ F test } & 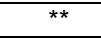 & ** & n.s & n.s & n.s & n.s & ** & ** & $* *$ & ** & ${ }^{* *}$ & ** \\
\hline \multicolumn{3}{|c|}{ L.S.D. 0.05} & 9.99 & 9.38 & - & - & - & - & 1.50 & 1.52 & 4.4 & 7.84 & 2.14 & 4.34 \\
\hline
\end{tabular}

N1, N2, N3 are nitrogen levels; S1, S2, S3, S4 are Azotobacter transformants; M1 and M2 are inoculation methods

Table (3): Effects of Azotobacter transformants and chemical nitrogen rates on growth characters and yield

\begin{tabular}{|c|c|c|c|c|c|c|c|c|c|c|c|c|c|c|}
\hline \multirow[t]{2}{*}{$\mathbf{N}$} & \multirow[t]{2}{*}{$\mathbf{M}$} & \multirow[t]{2}{*}{$\mathbf{S}$} & \multicolumn{2}{|c|}{$\begin{array}{l}\text { No. of fruits/ } \\
\text { plant }\end{array}$} & \multicolumn{2}{|c|}{$\begin{array}{c}\text { Weight of } \\
\text { fruits }\end{array}$} & \multicolumn{2}{|c|}{$\begin{array}{l}\text { No. of leaves/ } \\
\text { plant (45d) }\end{array}$} & \multicolumn{2}{|c|}{$\begin{array}{l}\text { No. of leaves/ } \\
\text { plant }(60 \mathrm{~d})\end{array}$} & \multicolumn{2}{|c|}{$\begin{array}{c}\text { Stem length } \\
(45 \mathrm{~d})\end{array}$} & \multicolumn{2}{|c|}{$\begin{array}{c}\text { Stem length } \\
(60 \mathrm{~d})\end{array}$} \\
\hline & & & 2004 & 2005 & 2004 & 2005 & 2004 & 2005 & 2004 & 2005 & 2004 & 2005 & 2004 & 2005 \\
\hline $\mathrm{N} 1$ & 1 & 1 & 820.8 & 662.7 & 7.627 & 6.297 & 25.63 & 25.54 & 17.50 & 19.00 & 94.83 & 93.83 & 129.8 & 125.9 \\
\hline $\mathrm{N} 2$ & 1 & 1 & 691.9 & 599.9 & 6.454 & 5.628 & 25.42 & 23.50 & 16.63 & 14.92 & 93.33 & 94.21 & 132.8 & 135.4 \\
\hline $\mathrm{NO}$ & 1 & 1 & 643.0 & 602.6 & 5.953 & 5.419 & 17.40 & 15.17 & 23.29 & 16.38 & 80.54 & 77.04 & 110.9 & 111.7 \\
\hline \multicolumn{3}{|l|}{$\mathrm{F}$ test } & $\star * *$ & $\star * *$ & $* *$ & $* *$ & ${ }^{* *}$ & ${ }^{* *}$ & $\star *$ & $* *$ & ${ }^{* *}$ & $* *$ & ** & ${ }^{* *}$ \\
\hline \multicolumn{3}{|c|}{ L.S.D. 0.05} & 29.6 & 36.6 & 0.506 & 0.290 & 0.99 & 1.64 & 3.43 & 3.14 & 2.28 & 5.69 & 6.52 & 5.15 \\
\hline 1 & M1 & 1 & 736.4 & 634.9 & 7.046 & 6.028 & 23.25 & 22.53 & 21.72 & 19.83 & 94.67 & 91.83 & 128.9 & 123.2 \\
\hline 1 & M2 & 1 & 700.8 & 608.6 & 6.310 & 5.535 & 22.38 & 20.28 & 16.56 & 13.69 & 84.47 & 84.89 & 120.1 & 125.5 \\
\hline \multicolumn{3}{|l|}{ F test } & 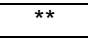 & n.s & ** & ${ }^{\star * *}$ & n.s & n.s & $\star \star *$ & ${ }^{* *}$ & ${ }^{* *}$ & ${ }^{* *}$ & $\star *$ & n.s \\
\hline 1 & 1 & S 1 & 770.8 & 672.2 & 7.057 & 6.079 & 21.22 & 21.06 & 22.39 & 17.39 & 90.78 & 86.28 & 123.6 & 123.3 \\
\hline 1 & 1 & S2 & 715.3 & 620.9 & 6.576 & 5.839 & 22.06 & 20.00 & 18.56 & 17.28 & 95.72 & 93.17 & 126.4 & 123.5 \\
\hline 1 & 1 & S3 & 688.4 & 600.1 & 6.427 & 5.530 & 22.78 & 20.17 & 17.50 & 15.94 & 84.44 & 84.28 & 123.1 & 123.5 \\
\hline 1 & 1 & S 4 & 699.7 & 593.8 & 6.651 & 5.677 & 25.19 & 24.39 & 18.11 & 16.44 & 87.33 & 89.72 & 124.9 & 126.7 \\
\hline \multirow{2}{*}{\multicolumn{3}{|c|}{ F test }} & $\star \star \star *$ & ${ }^{\star *}$ & $\star *$ & $* *$ & ${ }^{*}$ & $* \star$ & $\star \star *$ & n.s & $\star \star *$ & $\star *$ & n.s & n.s \\
\hline L.S.D. & & & 23.9 & 30.6 & 0.300 & 0.283 & 2.13 & 2.37 & 1.80 & & 4.75 & 4.92 & & \\
\hline
\end{tabular}

N1, N2, N3 are nitrogen levels; S1, S2, S3, S4 are Azotobacter transformants; M1 and M2 are inoculation methods 
Hassan,E.A. et al. 
Table (4): Effects of Azotobacter transformants and chemical nitrogen rates on growth characters and yield (gm/plant) of cucumber seasons 2004 and 2005.

\begin{tabular}{|c|c|c|c|c|c|c|c|c|c|c|c|c|c|c|}
\hline \multirow[t]{2}{*}{$\mathbf{N}$} & \multirow[t]{2}{*}{ M } & \multirow[t]{2}{*}{$S$} & \multicolumn{2}{|c|}{$\begin{array}{c}\text { No. of } \\
\text { fruits/plant }\end{array}$} & \multicolumn{2}{|c|}{$\begin{array}{l}\text { Weight of } \\
\text { fruits }\end{array}$} & \multicolumn{2}{|c|}{$\begin{array}{l}\text { No. of leaves/ } \\
\text { plant (45d) }\end{array}$} & \multicolumn{2}{|c|}{$\begin{array}{l}\text { No. of leaves/ } \\
\text { plant (60d) }\end{array}$} & \multicolumn{2}{|c|}{$\begin{array}{l}\text { Stem length } \\
(45 \mathrm{~d})\end{array}$} & \multicolumn{2}{|c|}{$\begin{array}{l}\text { Stem length } \\
(60 \mathrm{~d})\end{array}$} \\
\hline & & & 2004 & 2005 & 2004 & 2005 & 2004 & 2005 & 2004 & 2005 & 2004 & 2005 & 2004 & 2005 \\
\hline N1 & M1 & 1 & 290.5 & 267.9 & 29.49 & 22.94 & 78.50 & 102.92 & 27.42 & 35.08 & 158.0 & 172.3 & 69.75 & 66.17 \\
\hline N1 & M 2 & 1 & 281.3 & 244.9 & 28.58 & 20.88 & 64.83 & 96.33 & 25.42 & 30.00 & 154.5 & 180.0 & 76.92 & 67.17 \\
\hline N2 & M1 & 1 & 191.6 & 206.1 & 19.36 & 18.26 & 60.33 & 91.08 & 25.33 & 21.17 & 123.7 & 171.9 & 45.67 & 45.75 \\
\hline N2 & M2 & 1 & 162.9 & 226.8 & 16.82 & 18.38 & 69.08 & 76.92 & 23.08 & 27.58 & 126.5 & 147.9 & 45.50 & 50.58 \\
\hline No & M1 & 1 & 142.4 & 180.5 & 13.72 & 15.16 & 82.33 & 85.00 & 21.50 & 19.68 & 110.2 & 122.5 & 43.25 & 39.25 \\
\hline No & M2 & 1 & 125.4 & 195.5 & 12.83 & 16.57 & 59.83 & 65.75 & 20.25 & 19.21 & 112.0 & 133.8 & 42.67 & 39.75 \\
\hline \multicolumn{3}{|c|}{ F test } & n.s & & n.s & n.s & & n.s & n.s & & n.s & & & n.s \\
\hline \multicolumn{3}{|c|}{ L.S.D. 0.05} & - & 13.2 & - & - & 14.23 & - & - & 3.55 & - & 14.53 & 4.60 & - \\
\hline N1 & M1 & S 1 & 258.1 & 245.6 & 27.98 & 23.84 & 65.33 & 96.67 & 23.17 & 31.83 & 148.8 & 166.7 & 61.17 & 59.00 \\
\hline N1 & M2 & S2 & 250.5 & 244.7 & 29.95 & 21.71 & 71.00 & 95.00 & 27.33 & 33.50 & 156.0 & 177.5 & 63.00 & 57.50 \\
\hline N1 & M1 & 53 & 301.7 & 259.9 & 28.10 & 21.08 & 68.33 & 96.83 & 25.33 & 29.00 & 152.7 & 176.2 & 79.00 & 68.50 \\
\hline N1 & M2 & S 4 & 333.3 & 275.6 & 30.11 & 21.00 & 82.00 & 110.00 & 29.83 & 35.83 & 167.5 & 184.2 & 90.17 & 81.67 \\
\hline N2 & M1 & S 1 & 174.5 & 210.0 & 17.90 & 17.60 & 70.00 & 85.50 & 24.83 & 23.83 & 127.3 & 145.8 & 42.50 & 44.67 \\
\hline N2 & M2 & S2 & 180.0 & 200.5 & 18.73 & 19.27 & 68.17 & 89.00 & 24.50 & 23.50 & 113.7 & 145.8 & 49.33 & 49.33 \\
\hline N2 & M1 & 53 & 181.8 & 234.2 & 18.53 & 17.98 & 54.00 & 78.50 & 21.67 & 23.67 & 132.7 & 172.5 & 45.17 & 46.83 \\
\hline N2 & M2 & S4 & 172.3 & 221.2 & 17.20 & 18.43 & 66.67 & 83.00 & 25.83 & 26.50 & 126.7 & 166.5 & 45.33 & 51.83 \\
\hline N3 & M1 & S1 & 135.3 & 181.6 & 13.85 & 14.96 & 73.33 & 71.83 & 19.67 & 18.08 & 110.2 & 127.5 & 40.50 & 39.17 \\
\hline N3 & M 2 & 52 & 132.3 & 174.4 & 13.78 & 15.69 & 66.00 & 75.00 & 20.67 & 18.58 & 105.7 & 128.3 & 42.83 & 39.67 \\
\hline N3 & M1 & 53 & 128.8 & 210.2 & 12.32 & 17.52 & 74.33 & 83.00 & 21.83 & 20.33 & 110.7 & 122.5 & 40.50 & 36.33 \\
\hline N3 & M2 & S4 & 139.5 & 185.7 & 13.13 & 15.29 & 70.67 & 71.67 & 21.33 & 20.78 & 117.8 & 134.2 & 48.00 & 42.83 \\
\hline \multicolumn{3}{|c|}{ F test } & & & & n.s & & & & & & n.s & & \\
\hline \multicolumn{3}{|c|}{ L.S.D. 0.05} & 17.31 & 16.2 & 1.54 & - & 9.46 & 5.02 & 2.53 & 2.62 & 8.93 & 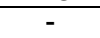 & 3.72 & 7.60 \\
\hline 1 & M1 & S 1 & 202.4 & 200.0 & 21.42 & 18.49 & 74.78 & 91.56 & 23.00 & 24.67 & 129.8 & 149.4 & 48.33 & 47.11 \\
\hline 1 & M1 & 52 & 199.8 & 213.2 & 20.76 & 20.30 & 73.89 & 91.33 & 25.89 & 22.83 & 130.8 & 157.7 & 47.89 & 46.00 \\
\hline 1 & M1 & S3 & 221.1 & 226.3 & 20.75 & 18.66 & 67.78 & 92.78 & 22.44 & 25.00 & 127.6 & 155.2 & 49.67 & 47.56 \\
\hline 1 & M1 & S4 & 209.3 & 233.2 & 20.49 & 17.70 & 78.44 & 96.33 & 27.67 & 28.74 & 134.3 & 159.9 & 65.67 & 60.89 \\
\hline 1 & M2 & S1 & 176.2 & 224.8 & 18.40 & 19.11 & 64.33 & 77.78 & 22.11 & 24.50 & 127.8 & 143.9 & 47.78 & 48.11 \\
\hline 1 & M2 & S 2 & 175.4 & 199.8 & 20.89 & 17.48 & 62.89 & 81.33 & 22.44 & 27.56 & 119.4 & 149.4 & 55.56 & 51.67 \\
\hline 1 & M2 & 53 & 187.1 & 243.2 & 18.55 & 19.06 & 63.33 & 79.44 & 23.44 & 23.67 & 136.4 & 158.9 & 60.11 & 53.56 \\
\hline 1 & M2 & S4 & 220.8 & 221.7 & 19.80 & 18.78 & 67.78 & 89.11 & 23.67 & 26.67 & 140.3 & 163.3 & 56.67 & 56.67 \\
\hline \multirow{2}{*}{\multicolumn{3}{|c|}{\begin{tabular}{|l|} 
F test \\
$S D$
\end{tabular}}} & & & n.s & n.s & n.s & n.s & & & & & & \\
\hline & & & 9.99 & 9.38 & - & - & - & - & 1.50 & 1.52 & 4.4 & 7.84 & 2.14 & 4.34 \\
\hline
\end{tabular}

N1, N2, N3 are nitrogen levels; S1, S2, S3, S4 are Azotobacter transformants; M1 and M2 are inoculation methods 
Hassan,E.A. et al.

Table (5): Effects of Azotobacter transformants and chemical nitrogen rates on growth characters and yield \begin{tabular}{|l|l|l|l|l|}
\hline (gm/plant) of Okra seasons 2004 and 2005. \\
\hline
\end{tabular}

\begin{tabular}{|c|c|c|c|c|c|c|c|c|c|c|c|c|c|c|}
\hline \multirow[t]{2}{*}{$\mathbf{N}$} & \multirow[t]{2}{*}{$M$} & \multirow[t]{2}{*}{$\mathbf{S}$} & \multicolumn{2}{|c|}{$\begin{array}{c}\text { No. of } \\
\text { fruits/plant }\end{array}$} & \multicolumn{2}{|c|}{ Weight of fruits } & \multicolumn{2}{|c|}{$\begin{array}{l}\text { No. of leaves/ } \\
\text { plant (45d) }\end{array}$} & \multicolumn{2}{|c|}{$\begin{array}{l}\text { No. of leaves/ } \\
\text { plant (60d) }\end{array}$} & \multicolumn{2}{|c|}{$\begin{array}{l}\text { Stem length } \\
(45 \mathrm{~d})\end{array}$} & \multicolumn{2}{|c|}{$\begin{array}{c}\text { Stem length } \\
(60 \mathrm{~d})\end{array}$} \\
\hline & & & 2004 & 2005 & 2004 & 2005 & 2004 & 2005 & 2004 & 2005 & 2004 & 2005 & 2004 & 2005 \\
\hline $\mathrm{N1}$ & M1 & 1 & 768.8 & 652.4 & 7.429 & 6.183 & 25.92 & 26.50 & 19.08 & 22.00 & 96.83 & 95.00 & 131.6 & 126.8 \\
\hline $\mathrm{N1}$ & $\mathrm{M} 2$ & 1 & 872.8 & 672.9 & 7.825 & 6.410 & 25.33 & 24.58 & 15.92 & 16.00 & 92.83 & 92.67 & 128.1 & 125.0 \\
\hline N2 & M1 & 1 & 753.8 & 582.3 & 7.341 & 6.133 & 24.58 & 25.33 & 16.17 & 17.83 & 97.58 & 95.83 & 140.8 & 131.9 \\
\hline N2 & M2 & 1 & 629.9 & 634.7 & 5.567 & 5.123 & 26.25 & 21.67 & 17.08 & 12.00 & 89.08 & 92.58 & 124.7 & 138.9 \\
\hline No & M1 & 1 & 686.4 & 570.6 & 6.368 & 5.767 & 19.25 & 15.75 & 29.92 & 19.67 & 71.50 & 84.67 & 114.3 & 110.8 \\
\hline No & M2 & 1 & 599.7 & & 5.538 & 5.072 & 15.54 & 14.58 & 16.67 & 13.08 & & 69.42 & 107.6 & 112.6 \\
\hline \multirow{2}{*}{\multicolumn{3}{|c|}{$\begin{array}{l}\text { F test } \\
\text { L.S.D. } 0.05\end{array}$}} & & n.s & & & & n.s & & n.s & $\star \star \star ~$ & & n.s & n.s \\
\hline & & & 32.1 & - & 0.503 & 0.484 & 2.66 & & 3.70 & 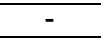 & 4.18 & 3.44 & - & 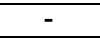 \\
\hline $\mathrm{N} 1$ & M1 & S 1 & 920.7 & 729.0 & 8.492 & 6.48 & 22.33 & 24.17 & 25.33 & 21.50 & 90.83 & 85.83 & 134.5 & 126.7 \\
\hline $\mathrm{N1}$ & $\mathrm{M} 2$ & S2 & 784.5 & 633.0 & 7.295 & 6.463 & 24.50 & 23.50 & 16.83 & 20.17 & 99.33 & 98.33 & 125.3 & 123.5 \\
\hline N1 & M1 & S 3 & 801.2 & 636.8 & 7.437 & 5.985 & 26.83 & 25.00 & 14.50 & 17.76 & 94.00 & 92.00 & 127.3 & 126.3 \\
\hline N1 & M2 & S 4 & 776.8 & 651.8 & 7.285 & 6.330 & 28.83 & 29.50 & 13.33 & 16.67 & 95.17 & 99.17 & 132.2 & 127.2 \\
\hline N2 & M1 & S 1 & 704.8 & 679.2 & 6.665 & 6.483 & 24.00 & 22.17 & 18.83 & 14.67 & 101.50 & 96.67 & 123.0 & 126.2 \\
\hline $\mathrm{N} 2$ & M2 & S2 & 735.0 & 631.2 & 6.413 & 5.63 & 22.17 & 22.17 & 15.50 & 15.50 & 92.76 & 95.00 & 133.5 & 132.7 \\
\hline N2 & M1 & S 3 & 629.2 & 536.0 & 6.073 & 5.125 & 25.50 & 21.83 & 18.17 & 14.83 & 86.83 & 88.17 & 140.7 & 140.0 \\
\hline N2 & M2 & S 4 & 698.5 & 553.3 & 6.663 & 5.238 & 30.00 & 27.83 & 14.00 & 14.67 & 92.33 & 97.00 & 133.8 & 142.8 \\
\hline N3 & M1 & S 1 & 687.0 & 608.3 & 6.015 & 5.347 & 17.33 & 16.83 & 23.00 & 16.00 & 80.00 & 76.33 & 113.3 & 117.0 \\
\hline N3 & M2 & S 2 & 626.5 & 598.5 & 6.018 & 5.388 & 19.50 & 14.33 & 23.33 & 16.17 & 95.17 & 86.17 & 120.5 & 115.7 \\
\hline N3 & M1 & S 3 & 634.8 & 627.3 & 5.772 & 5.480 & 16.00 & 12.67 & 19.83 & 15.33 & 72.50 & 72.67 & 101.2 & 104.2 \\
\hline N3 & M2 & S 4 & 623.8 & 576.3 & 6.005 & 5.462 & 16.75 & 15.83 & 27.00 & 18.00 & 74.50 & 73.00 & 108.7 & 110.0 \\
\hline \multirow{2}{*}{\multicolumn{3}{|c|}{$\begin{array}{l}\text { F test } \\
\text { L.S.D. } 0.05 \\
\end{array}$}} & & & & & & $n-s$ & & $n-s$ & & & & \\
\hline & & & 23.4 & 53.0 & 0.520 & 0.491 & 3.09 & - & 3.12 & - & 8.23 & 5.51 & 4.74 & 9.80 \\
\hline 1 & M1 & S 1 & 786.3 & 685.0 & 7.421 & 6.223 & 22.33 & 23.67 & 25.67 & 20.89 & 97.89 & 91.67 & 128.6 & 126.8 \\
\hline 1 & M1 & S2 & 711.6 & 633.0 & 6.524 & 5.992 & 24.22 & 22.78 & 22.89 & 20.33 & 102.56 & 99.56 & 124.1 & 120.9 \\
\hline 1 & M1 & S3 & 724.6 & 627.0 & 7.023 & 5.967 & 21.11 & 18.89 & 18.11 & 19.67 & 83.89 & 84.56 & 128.4 & 119.9 \\
\hline 1 & M1 & S 4 & 723.0 & 594.4 & 7.214 & 5.928 & 25.33 & 24.78 & 20.22 & 18.44 & 94.33 & 91.56 & 134.4 & 125.2 \\
\hline 1 & M2 & S 1 & 755.3 & 659.3 & 6.693 & 5.936 & 20.11 & 18.44 & 19.11 & 13.89 & 83.67 & 80.89 & 118.7 & 119.8 \\
\hline 1 & M2 & S2 & 719.1 & 608.8 & 6.627 & 5.686 & 19.89 & 17.22 & 14.22 & 14.22 & 88.89 & 86.78 & 128.8 & 127.0 \\
\hline 1 & M2 & S 3 & 652.2 & 573.1 & 5.831 & 5.093 & 24.44 & 21.44 & 16.89 & 12.22 & 85.00 & 84.00 & 117.7 & 127.1 \\
\hline 1 & M2 & S 4 & 676.4 & 593.2 & 6.088 & 5.426 & 25.06 & 24.00 & 16.00 & 14.44 & 80.33 & 87.89 & 115.3 & 128.1 \\
\hline \multirow{2}{*}{\multicolumn{3}{|c|}{$\begin{array}{l}\text { F test } \\
\text { L.S.D. } 0.05\end{array}$}} & & n.s & & n.s & & & & n.s & & & & n.s \\
\hline & & & 33.7 & & 0.425 & & 3.01 & 2.37 & 2.55 & & 6.72 & 6.45 & 7.44 & \\
\hline
\end{tabular}


Table (6): Effects of Azotobacter transformants and chemical nitrogen rates on growth characters and yield (gm/plant) of cucumber seasons 2004 and 2005.

\begin{tabular}{|c|c|c|c|c|c|c|c|c|c|c|c|c|c|c|}
\hline \multirow[t]{2}{*}{$\mathbf{N}$} & \multirow[t]{2}{*}{ M } & \multirow[t]{2}{*}{$\mathbf{S}$} & \multicolumn{2}{|c|}{$\begin{array}{l}\text { No. of fruits/ } \\
\text { plant }\end{array}$} & \multicolumn{2}{|c|}{$\begin{array}{c}\text { Weight of } \\
\text { fruits/plant }\end{array}$} & \multicolumn{2}{|c|}{$\begin{array}{l}\text { Stem length } \\
(45 \mathrm{~d}))\end{array}$} & \multicolumn{2}{|c|}{$\begin{array}{l}\text { No. of leaves/ } \\
\text { plant (45d) }\end{array}$} & \multicolumn{2}{|c|}{$\begin{array}{l}\text { Stem length } \\
(60 \mathrm{~d})\end{array}$} & \multicolumn{2}{|c|}{$\begin{array}{l}\text { No. of leaves/ } \\
\text { plant (60d) }\end{array}$} \\
\hline & & & 2004 & 2005 & 2004 & 2005 & 2004 & 2005 & 2004 & 2005 & 2004 & 2005 & 2004 & 2005 \\
\hline N 1 & M 1 & S 1 & 284.5 & 241.6 & 29.57 & 24.68 & 73.67 & 100.33 & 26.33 & 34.33 & 153.7 & 168.3 & 85.00 & 58.00 \\
\hline N1 & M1 & 52 & 26.1 .0 & 255.4 & 29.60 & 21.53 & 75.00 & 101.00 & 24.67 & 33.00 & 170.0 & 183.3 & 57.00 & 55.00 \\
\hline N1 & M1 & 53 & 311.7 & 265.0 & 29.81 & 21.40 & 17.33 & 98.33 & 24.33 & 32.00 & 146.7 & 162.3 & 70.00 & 65.00 \\
\hline N1 & M1 & 54 & 304.7 & 309.7 & 28.98 & 24.16 & 94.00 & 112.00 & 34.33 & 14.00 & 161.7 & 175.0 & 94.00 & 86.67 \\
\hline N1 & M2 & S1 & 231.7 & 249.6 & 26.40 & 23.00 & 57.00 & 93.00 & 20.00 & 29.33 & 144.0 & 165.0 & 64.33 & 60.00 \\
\hline N1 & M2 & 52 & 240.0 & 233.9 & 30.30 & 21.89 & 67.00 & 89.00 & 30.00 & 34.00 & 142.0 & 171.7 & 69.00 & 60.00 \\
\hline N1 & M2 & 53 & 291.7 & 254.8 & 26.40 & 20.76 & 65.33 & 95.33 & 26.33 & 26.00 & 158.7 & 190.0 & 88.00 & 72.00 \\
\hline N1 & M2 & S4 & 362.0 & 241.4 & 31.23 & 17.58 & 70.00 & 108.00 & 25.33 & 30.67 & 173.3 & 193.3 & 86.33 & 76.67 \\
\hline N2 & M1 & S1 & 194.3 & 195.0 & 20.60 & 17.04 & 65.33 & 85.00 & 23.33 & 21.00 & 128.0 & 160.0 & 44.00 & 43.33 \\
\hline N2 & M1 & S2 & 200.7 & 202.1 & 20.13 & 21.49 & 66.33 & 97.00 & 30.00 & 18.33 & 115.7 & 169.7 & 46.67 & 44.67 \\
\hline N2 & M1 & 53 & 189.0 & 220.1 & 17.94 & 18.82 & 44.67 & 92.00 & 20.33 & 21.33 & 127.0 & 180.0 & 39.00 & 41.00 \\
\hline N2 & M1 & S4 & 182.3 & 207.3 & 18.77 & 15.69 & 65.00 & 90.33 & 27.67 & 24.00 & 124.0 & 178.0 & 53.00 & 54.00 \\
\hline N2 & M2 & S 1 & 155.3 & 225.0 & 15.20 & 18.17 & 74.67 & 86.00 & 26.33 & 26.67 & 126.7 & 131.7 & 41.00 & 46.00 \\
\hline N2 & M2 & 52 & 159.3 & 198.9 & 17.33 & 17.04 & 70.00 & 81.00 & 19.00 & 28.67 & 111.7 & 140.0 & 52.00 & 54.00 \\
\hline N2 & M2 & 53 & 174.7 & 248.2 & 19.11 & 17.14 & 63.33 & 65.00 & 23.00 & 26.00 & 138.3 & 165.0 & 51.33 & 52.67 \\
\hline N2 & M2 & S4 & 162.3 & 235.0 & 15.63 & 21.18 & 68.33 & 75.67 & 24.00 & 29.00 & 129.3 & 155.0 & 37.67 & 49.67 \\
\hline NB & M1 & S1 & 128.3 & 163.4 & 14.10 & 13.75 & 85.33 & 89.33 & 19.33 & 18.67 & 107.7 & 120.0 & 43.00 & 40.00 \\
\hline NB & M1 & 52 & 137.7 & 182.1 & 12.53 & 17.87 & 80.33 & 76.00 & 23.00 & 17.17 & 106.7 & 120.0 & 40.00 & 38.33 \\
\hline NB & M1 & 53 & 162.5 & 193.8 & 14.51 & 18.75 & 87.33 & 88.00 & 22.67 & 21.67 & 109.0 & 123.3 & 40.00 & 36.67 \\
\hline N B & M1 & S4 & 141.0 & 182.7 & 13.73 & 13.25 & 76.33 & 86.67 & 21.00 & 21.23 & 117.3 & 126.7 & 50.00 & 24.00 \\
\hline NB & M2 & S1 & 141.7 & 199.8 & 13.60 & 16.16 & 61.33 & 54.33 & 20.00 & 17.50 & 112.7 & 135.0 & 38.00 & 38.33 \\
\hline N B & M 2 & S2 & 127.0 & 166.7 & 15.03 & 13.51 & 51.67 & 74.00 & 18.33 & 20.00 & 104.7 & 136.7 & 45.67 & 41.00 \\
\hline N B & M2 & 53 & 95.0 & 226.6 & 10.14 & 19.29 & 61.33 & 78.00 & 21.00 & 19.00 & 112.3 & 121.7 & 41.00 & 36.00 \\
\hline NB & M2 & 54 & 138.0 & 188.8 & 12.53 & 17.33 & 65.00 & 56.67 & 21.67 & 20.33 & 118.3 & 141.7 & 46.00 & 43.67 \\
\hline \multirow{2}{*}{\multicolumn{3}{|c|}{$=$ test }} & & & & & n.s & & & n.s & & n.s & & n.s \\
\hline & & & 24.5 & 32.0 & 2.17 & 3.36 & - & 11.34 & 3.56 & - & 12.1 & - & 5.25 & \\
\hline
\end{tabular}

N1, N2, N3 are nitrogen levels; S1, S2, S3, S4 are Azotobacter transformants; M1 and M2 are inoculation methods 
Table (7): Effects of Azotobacter transformants and chemical nitrogen rates on growth characters and yield (gm/plant) of Okra seasons 2004 and 2005.

\begin{tabular}{|c|c|c|c|c|c|c|c|c|c|c|c|c|c|c|}
\hline \multirow[t]{2}{*}{$\mathbf{N}$} & \multirow[t]{2}{*}{$\mathbf{M}$} & \multirow[t]{2}{*}{ S } & \multicolumn{2}{|c|}{$\begin{array}{c}\text { No. of } \\
\text { fruits/plant }\end{array}$} & \multicolumn{2}{|c|}{$\begin{array}{l}\text { Weight of } \\
\text { fruits/plant }\end{array}$} & \multicolumn{2}{|c|}{$\begin{array}{l}\text { Stem length } \\
(45 \mathrm{~d}))\end{array}$} & \multicolumn{2}{|c|}{$\begin{array}{l}\text { No. of leaves/ } \\
\text { plant (45d) }\end{array}$} & \multicolumn{2}{|c|}{$\begin{array}{l}\text { Stem length } \\
(60 \mathrm{~d})\end{array}$} & \multicolumn{2}{|c|}{$\begin{array}{c}\text { No. of } \\
\text { leaves/plant }(60 \mathrm{~d}\end{array}$} \\
\hline & & & 2004 & 2005 & 2004 & 2005 & 2004 & 2005 & 2004 & 2005 & 2004 & 2005 & 2004 & 2005 \\
\hline N1 & M1 & S 1 & 866.7 & 755.3 & 8.477 & 6.493 & 27.00 & 26.67 & 27.33 & 26.33 & 98.67 & 91.67 & 144.7 & 139.7 \\
\hline N1 & M1 & 52 & 632.3 & 635.3 & 5.970 & 6.140 & 27.67 & 27.00 & 22.00 & 22.33 & 102.00 & 103.33 & 117.3 & 121.7 \\
\hline N1 & M1 & 53 & 796.0 & 610.3 & 7.700 & 6.043 & 20.67 & 23.33 & 13.33 & 23.00 & 93.00 & 90.00 & 133.7 & 123.3 \\
\hline N1 & M1 & S 4 & 780.3 & 608.7 & 7.570 & 6.057 & 28.33 & 29.00 & 13.67 & 16.33 & 39.67 & 95.00 & 130.7 & 122.7 \\
\hline N1 & M2 & S1 & 974.7 & 702.7 & 5.507 & 6.323 & 17.67 & 21.67 & 23.33 & 16.67 & 83.00 & 80.00 & 124.3 & 113.7 \\
\hline N1 & M 2 & 52 & 936.7 & 630.7 & 8.620 & 6.787 & 21.33 & 20.00 & 11.67 & 18.00 & 96.67 & 93.33 & 133.3 & 125.3 \\
\hline N1 & M 2 & 53 & 806.3 & 663.3 & 7.173 & 5.927 & 33.00 & 26.67 & 15.67 & 12.33 & 95.00 & 94.00 & 121.0 & 129.3 \\
\hline N1 & M 2 & 54 & 773.3 & 695.0 & 7.000 & 6.603 & 29.33 & 33.00 & 13.00 & 17.00 & 96.67 & 103.33 & 133.7 & 131.7 \\
\hline N2 & M1 & S1 & 747.3 & 669.0 & 7.357 & 6.753 & 22.67 & 25.00 & 18.33 & 16.33 & 102.67 & 96.67 & 117.7 & 114.0 \\
\hline N2 & M1 & 52 & 327.3 & 645.0 & 7.470 & 6.207 & 22.33 & 26.00 & 15.00 & 19.33 & 107.33 & 102.00 & 133.0 & 126.0 \\
\hline N2 & M1 & 53 & 707.0 & 564.0 & 7.323 & 5.380 & 22.67 & 21.00 & 16.33 & 18.00 & 73.67 & 81.67 & 150.0 & 139.7 \\
\hline N2 & M1 & S4 & 733.7 & 592.0 & 7.213 & 5.740 & 33.67 & 29.33 & 15.00 & 17.67 & 106.67 & 103.00 & 162.7 & 148.0 \\
\hline N2 & M 2 & S1 & 662.3 & 689.3 & 5.973 & 6.213 & 25.33 & 19.33 & 19.33 & 13.00 & 100.33 & 96.67 & 128.3 & 138.3 \\
\hline N2 & M2 & 52 & 642.7 & 617.3 & 5.357 & 5.123 & 22.00 & 18.33 & 16.00 & 11.67 & 78.00 & 88.00 & 134.0 & 139.3 \\
\hline N2 & M 2 & 53 & 551.3 & 508.0 & 4.823 & 4.420 & 28.33 & 22.67 & 20.00 & 11.67 & 100.00 & 94.67 & 131.3 & 140.3 \\
\hline N2 & M2 & 54 & 663.3 & 514.7 & 6.113 & 4.737 & 29.33 & 26.33 & 13.00 & 11.67 & 78.00 & 91.00 & 105.0 & 137.7 \\
\hline N B & M1 & S1 & 745.0 & 630.7 & 6.430 & 5.423 & 17.33 & 19.33 & 31.33 & 20.00 & 92.33 & 86.67 & 123.3 & 126.7 \\
\hline N B & M 1 & 52 & 675.0 & 618.7 & 6.133 & 5.630 & 22.67 & 15.33 & 31.67 & 19.33 & 98.33 & 93.33 & 122.0 & 115.0 \\
\hline N B & M1 & 53 & 670.7 & 706.7 & 6.047 & 6.027 & 20.00 & 12.33 & 24.67 & 18.00 & 85.00 & 82.00 & 101.7 & 96.7 \\
\hline N B & M1 & 54 & 655.0 & 582.7 & 6.860 & 5.987 & 17.00 & 16.00 & 32.00 & 21.33 & 82.67 & 76.67 & 110.0 & 105.0 \\
\hline NB & M2 & S 1 & 629.0 & 586.0 & 5.600 & 5.270 & 17.33 & 14.33 & 14.67 & 12.00 & 67.67 & 66.00 & 103.3 & 107.3 \\
\hline NB & M2 & 52 & 578.0 & 578.3 & 5.903 & 5.147 & 16.33 & 13.33 & 15.00 & 13.00 & 92.00 & 79.00 & 119.0 & 116.3 \\
\hline N B & M 2 & 53 & 599.0 & 548.0 & 5.497 & 4.933 & 12.00 & 15.00 & 15.00 & 12.67 & 60.00 & 63.33 & 100.7 & 111.7 \\
\hline N B & M2 & 54 & 592.7 & 570.0 & 5.150 & 4.937 & 16.50 & 15.67 & 22.00 & 14.67 & 66.33 & 69.33 & 107.3 & 115.0 \\
\hline$=$ test & & & & & & n.s & & n.s & n.s & & & & & \\
\hline .S.D & & & 58.4 & 26.1 & 0.735 & & 1.28 & & & 4.50 & 11.64 & 12.04 & 13.8 & 16.1 \\
\hline
\end{tabular}

N1, N2, N3 are nitrogen levels; S1, S2, S3, S4 are Azotobacter transformants; M1 and M2 are inoculation methods 